\title{
Poverty, child sexual abuse and HIV in the Transkei region, South Africa
}

*Banwari M

Department of Forensic Medicine Walter Sisulu University, South Africa

\begin{abstract}
Everyone loves children. They want them to be happy and prosperous, but poverty takes away their rights. Poverty even forces them to sell their daughters in exchange for money. The trio of poverty, sexual assaults and HIV are complimentary to one another.

This paper is a selection of 5 cases who presented at Sinawe Center as victims of rape, where money has played a role in the delay in reporting to the police. First, a young girl of 13 years was raped by a known person. The cost of settlement was a mere R500 (equivalent to 70 US dollars). The second victim was paid R10 or R20 for each sexual act. Third, fourth and fifth cases, were young girls who were forced to marry by their parents. The history, physical examination and laboratory investigations are given. Psychosocial and economic aspects are also discussed.
\end{abstract}

African Health Sciences 2011; 11(S1): S117 - S121

\section{Introduction}

Child sexual abuse is an old, global and complex phenomenon, which deprives children of their childhood, human rights, and dignity. It can be seen as the commercial sexual exploitation ${ }^{1}$. Poverty is the underlying cause of sexual exploitation of young girls in many parts of the world. Disclosing sexual abuse is a complex process. Much is hidden from the adult society, especially from professionals and the legal system² ${ }^{2}$ South Africa has one of the highest rates of sexual assaults in the world; with adolescent girls between the ages of 12 and 17 being particularly at risk ${ }^{3}$. Child rape is becoming more common in South Africa. In 2000, over 52,550 cases of rape or attempted rape of women were reported to South African Police Service ${ }^{4}$. Of these 21, 438 victims were minors under the age of 18 years, and 7,898 of these were under 12 years ${ }^{5}$. The widespread rape and sexual assaults of children is a serious social and health issue in the Transkei sub-region of the Eastern Cape Province in South Africa ${ }^{6}$.

Increasing levels of absolute poverty have been recorded in the Eastern Cape. Seventy four percent of the people of the Eastern Cape livs below the poverty line of R800 (equivalent to 105 US

\begin{tabular}{|l|}
\hline *Correspondence author \\
Meel Banwari \\
Department of Forensic Medicine, Walter Sisulu \\
University, South Africa \\
Email: bmeel@wsu.ac.za, bmeel@wsu.ac.za
\end{tabular}

African Health Sciences Vol 11 Special Issue 1 August 2011 dollars) or less per month. Poverty levels vary according to district but in Alfred Nzo District Municipality, $82.3 \%$ of the population lives below the poverty line which is much higher than the provincial norm. ${ }^{7}$ A traditional Southern African custom whereby the man pays the family of his fiancée for marriage is known as Lobola in Transkei, and Mahadi in Sesotho. It is translated as bride price ${ }^{8}$. Lobola is an age-old African custom that is as alive as it was 100 years ago. South Africa has the highest incidence of HIV/AIDS in the world; some claim that this high rate is partly due to the custom of Lobola' ${ }^{9}$. The lobola process is complicated and sometimes confusing for the modern couples. The negotiations can take up to two days and the talk will usually revolve around the number of cattle to be paid as the bride-price. However, there is a rule that follows before the actual wedding - the couple is usually forbidden from meeting until the actual wedding ceremony ${ }^{10}$. Many modern couples opt for cash instead of cows for the sake of convenience. This money can be used to help the bride set up her home; however, this is something that happens very rarely. ${ }^{11}$

Approximately $57 \%$ of individuals in South Africa were living below the poverty line in 2001 and this proportion had not changed between 1996 and 2001. However, those households living in poverty have sunk deeper into poverty and the gap between rich and poor has widened. ${ }^{12}$ Limpopo and 
the Eastern Cape had the highest percentages of poor with $77 \%$ and $72 \%$ of their populations living below the poverty line respectively. ${ }^{12}$ The rural people of South Africa are at greater risk of being poor. Transkei is an area where people are poor and living on meager resources. The Eastern Cape has the highest percentage of poor (24\%), and this figure rises to $92 \%$ in Transkei region. ${ }^{13}$

In economically poor countries young girls take to prostitution. It is a sign of poverty and economic distress. A study carried out in India (1995) showed that girl prostitutes are primarily located in low-middle income areas and business districts and are known by officials. UNICEF estimates about 300000 child prostitutes are in India. A little over $50 \%$ of prostitutes come from neighboring poor countries like Nepal and Bangladesh. ${ }^{14}$ The purpose of these case reports is to highlight the problem of poverty, sexual assaults and HIV/AIDS in this region of Transkei, South Africa.

\section{Methods}

This is a retrospective qualitative study from the records of Sinawe center. All records of cases brought by police in the year 2009 were available. The Sinawe Centre is the only center in this region whicg deals with cases of sexual abuse. All the cases of abuse were examined by qualified medical practitioners. There are 4 doctors, 10 nursing staff and 5 supportive staff employed in this center. This center provides the services during working hours and on week ends including holidays. It caters for a population of about 400,000 in this region. The detailed history of sexual abuse was taken by nursing staff directly from the subjects. The peculiarity in selection of these cases is based on the history of exchange of money for either sex or 'labola' taken by parents. The informed consent was taken prior to examination either from the patient or from the guardian by the nursing staff at the time of counseling. The names of subjects were always kept anonymous. The case history and findings of physical examination are described in this study.

\section{Case history}

1. PM, a 13 year old girl was brought by a policewoman with her grandmother after an alleged rape in October 2009. The victim was on the way to church for a night service. The perpetrator grabbed her and took her to a room where he tried to coerce her to have sex. When she refused she ended up being raped twice. The perpetrator was known to her. She was allowed to return home the following morning. The victim's relatives discussed the matter with relatives of the perpetrator, and it was agreed that R500 and a goat be given to the family as compensation.

Recently the grandmother noticed a yellowish discharge in the genital region and she took the girl back to the perpetrator who gave her herbal medicine to treat the discharge. The grand mother refused the offer and the perpetrator also did not pay her. Therefore the grand mother reported the incidence to the police.

On genital examination, the hymen was ruptured and foul smelling yellowish pus was pouring out from the vagina. She was negative for HIV, but weakly positive for syphilis. HIV post exposure prophylaxis was not indicated.

2. ZM, a 17 year old girl accompanied by her sister and police officers, presented to the Sinawe Center with a history of repeated rape. She was raped by an old man of 46 years who is a neighbor. The victim stated that she did not tell her mother and her sister because the perpetrator threatened to kill her if she disclosed. The victim told during history that the perpetrator used to give her money - R10 or R20 after doing this. Her mother is not working and gets a foster care grant for the child. The older brother who is working as a policeman is not supporting them, as he has his own family in Pretoria.

On genital examination, there was a ruptured hymen. There was an increased in friability with bruised introitus. Rapid test was non-reactive to HIV, and syphilis. HIV prophylaxis was not indicated.

3. VS, a 17 year old girl complained that she was forced to marry a man whom she did not like. She decided to run away from his house but her parents returned her back to his home and beat her. Ultimately she managed to run away. On genital examination, there was old ruptured hymen with fresh tears on 9 O'clock position. There is increased friability with bruised introitus. She was negative for HIV and syphilis. Post-exposure prophylaxis was not given as she presented late to the center.

4. Miss NM, a 20 year old student presented with a history of physical abuse. She was a standard 10 pupil from East London. She was staying with her aunt who was helping in her education after her father deserted the unemployed illiterate mother. She had come to visit her mother and siblings when she saw her long lost father. 
Her father had already plotted her marriage to a strange man who was an ex-soldier with his salary package. She was abducted and forced to marry this stranger. The man raped her and claimed her to be the wife from there on. She was repeatedly raped and when she fell sick and mentally depressed, was taken to a doctor after a week. On genital examination, there was recent ruptured hymen with bruised introitus. Rapid test was negative to HIV. Post-exposure prophylaxis was not indicated as she presented after 72 hours.

5. SS, a 17 year old girl was brought by the police with a history of abduction and rape. The victim was sent by her grand father to a certain location in exchange of money (Lobola). On the way she was confronted by three males, who grabbed and took her to an empty house. Later two women came to the house. One of them told the victim that she was no longer going back to her home. A man sexually assaulted her. She already had a boyfriend and had slept with him about a month before. The man who assaulted her did not use a condom. She was HIV negative, and post exposure prophylaxis was not given as she presented after 72 hours.

\section{Discussion}

Transkei is one of the former black homelands. Now it is part of the Eastern Cape Province of South Africa. The majority of the people living in this region are Xhosa. They have their own traditions about child birth, death and marriages. Most of the customary marriages are arranged between parents of brides and bridegrooms. Things are changing now and many couple just ignore their customs. This has become intolerable for the people of old generations and results in conflict within families. These five cases are a tip of an iceberg where money is the solution to settlement of rape perpetuated by a stranger.

\section{Forced marriages}

The 13 year old girl's (PM) issue was sorted out for R500. The parents just ignored all their responsibilities for monetary gains. The perpetrator himself was poor and so could not pay when the girl had to go to hospital. If he had given more money, the girl's family would not have reported to police, and therefore there would not have been a court case. Many perpetrators who could afford to pay, easily bypass the legal system. Threatening of victims is very common and prevents reporting to police. This happened to ZM. She was threatened with death but he paid her off with small amounts of R10 or R20 for each sexual act. The girl reported to her mother after almost 5 months. Sometimes these cases are only reported after pregnancy is detected. Many parents want to force their girls to marry as they are interested in financial gains as in the case of VS. She complained about the forced marriage on arrival at the Sinawe center. When she returned home she was assaulted by parents and forced to go back to the stranger. Similarly NM's father arranged marriage without her consent, yet she had seen him after many years as he had left them a long time ago. He wanted to organize a marriage for her for his financial gains. The man who was an ex-soldier paid money to the father. The prevalence of HIV (23\%) among defense force personnel is relatively high ${ }^{15}$ and so this girl was at a high risk of contracting the infection.

\section{Marriage and constitution}

In terms of customary law it is possible to abduct a girl to another family in order to force her family to give permission for the marriage. This is known as ukuthwala. ${ }^{16}$ It has been alleged that parents would push their daughters into such marriages because they were only interested in the financial benefits in the form of lobola. In some cases, girls have even been kidnapped by relatives and taken to the homes of their prospective husbands. Many of these girls were also at risk of contracting HIV because their husbands were migrant workers in Johannesburg. Forced marriage (Unkuthwala) is contrary to the country's constitution. These parents who forced their daughters to get married at a young age were "committing sins." It is illegal and unacceptable. It is also illegal to impregnate young girls at a young age. ${ }^{17}$

SS was abducted similarly to NM. The grand father sent three men who grabbed her at an isolated place. Two women came to the house and gave the message that she was no longer going back home. According to the Domestic Violence Act No. 116 of 1998, the right of this woman was being violated. The father had broken the trust as he abandoned them when they were young. The mother had struggled to bring up NM. This father saw his children as income generating assets can be exchanged for cash or cows.

\section{Poverty and Marriage}

Poverty plays a role in these kinds of forced marriages. The concept of Lobola was good in the olden days, when this was considered as a gift, but 
in the present day it has become a business to get money. The Pondo King announced that he would ban the age-old traditional customs of forced marriages in Eastern Pondoland. This ban came two weeks after the Commission for gender equality conducted an awareness campaign in Lusikiski. The authorities criminalized the outdated practice of forcing underage girls into marriage. ${ }^{17}$ The modern usage of lobola does not have a happy outcome as there are many instances where families use it to pay their debts. Some men see women as 'goods' that have been paid for as in the case of $\mathrm{VN}, \mathrm{MN}$ and SS. They were all sold out for money by their parents, especially fathers. Probably, poverty compels them to do so but such types of marriage as mentioned are not conducive to trust and love. Moreover, wives cannot obtain divorce from their abusive husbands because the families cannot pay back the lobola. This will turn into domestic violence later in their life.

\section{HIV and Lobola}

South Africa currently has more people infected with HIV (approximately 6.5 million) than any other country in Africa. ${ }^{18}$ There is even a reported relationship between the lobola and the spread of HIV/AIDS. South Africa has the highest incidence of HIV/AIDS in the world and some claim that this high rate is partly due to the custom of Lobola, which is seen as a monetary transaction. The wife is a bought object and the husband often feels free to acquire mistresses. This increases the possibility of infection, which is turn can be transmitted to the wife. ${ }^{10}$ The rate of sexual assault runs parallel with HIV prevalence. In the face of an explosive HIV/ AIDS epidemic, the South African government pledged to provide HIV post-exposure prophylaxis, if the survivors of rape present within 72 hours of the event. ${ }^{19}$ None of them qualified for HIV postexposure prophylaxis as they reported too late.

\section{Mental Health}

The range of mental health and social difficulties is wide and multiple among victims of sexual assaults. It varies in different countries and in different regions within a country. It depends upon the local beliefs and cultural practices. The victims are tense and face increased risk of mental disorders like NM who is sick and mentally depressed. Some of them could lead to suicide. A study carried out in United Kingdom, on 121 victims of sexual assault has shown that $8 \%$ have tense learning difficulties, $21 \%$ gave history of deliberate self-harm, and $20 \%$ presented with psychiatric problems. ${ }^{20}$ Early assessment is important because it enables vulnerable cases to be identified, and psychotherapy to be instituted.

The forced marriages and rape for money in this community are on rife. Lobola becomes a livelihood for the poverty stricken parents. It is a desperate situation, where HIV is not an important issue for a poor man.

Poverty alleviation is not only important to feed a human being but it is also important to bring morality among people and to control increasing HIV infection in the community.

\section{References}

1. Lau C. Child prostitution in Thailand. J Child Health Car, 2008; 2(2):44-55.

2. Priebe G, Svedin CG. Child sexual abuse is largely hidden from the adult society. An epidemiological study of adolescents' disclosures. Child Abuse Neglect 2008; 32(12):1095108.

3. Petersen I, Bhana A, McKay M. Sexual violence and youth in South Africa: The need for community-based prevention interventions. Child Abuse Negect 2005; 29(11):1233-48.

4. South African Police Service. Rape statistics in South Africa, 2000. wnw.capegateway.gov.za/eng/ pubs/public_info/C/ (Accessed 15.06.2010).

5. Sexual Assault Policy Draft. Sexual assault care practitioners' training workshop 2002; 11-13 July, Pretoria, South Africa.

6. Meel BL.The myth of child rape as a cure for HIV/AIDS in Transkei: A case report. Med Sci Law. 2003; 43(1):85-8.

7. Statistics South Africa. Community Survey 2007. Eastern Cape Department of Social Development. http://www.socdev.ecprov.gov.za/districts (Accessed 12.02.2010)

8. Wikipedia. Lobola, 2009. http:// en.wikipedia.org/wiki/Lobolo (Accessed 12.02.2010).

9. Smith G. Marriage tradition in Africa: lobola, 2002. http:// www.essortment.com/all / africanmarriage_rntr.htm (Accessed 12.02.2010).

10. World On Web. Marriage tradition in Africa: Lobola, 2009 http://www.gm/africa/southafrica/article/2007/10/1/marriage-tradition-inafrica-lobola (Accessed 15.06.2010).

11. Lana A. South African traditional marriage customs: Lobola and poly gamy. http:// www.southafricaweb.co.za/article/south- 
african-traditional-marriage-customs-lobola (Accessed 12.02.2010).

12. Southern African Regional Poverty Network. Fact Sheet: Poverty in South Africa, 2004. Human SciencesResearch Council. Website: http:// www.sarpn.org.za (Accessed 25.12.2009).

13. African National Congress. Rural Development Strategy of the Government of National Unity. Website:http:/ / www.anc.org.za/rdp/ rural2.html (accessed15.06.2010).

14. Mukhopadhyay KK. Girl prostitution in India. Soc Chang, 1995; 25(2-3):143-53.

15. Centers for disease control and prevention (US). Nearly one-fourth of South African Soldiers Contract HIV/AIDS, 2004. International News. Website: www.thebody.com/content/ art27213.html (Accessed 15.05.2010).

16. Herbst M, du Plessis W. Customary Law v Common Law Marriages: A hybrid approach in South Africa. Electronic J of Comparative Law, 2008; 12(1):1-15.

17. Hans B. King bans forced marriages. Underage girls now 'safe' in Eastern Pondoland. Daily dispatch, 2009, page 1, Friday April 10.

18. Berry L, Guthrie T. The situation of children in South Africa. Children's institute. University of Cape Town, 2003.

19. Department of Health Policy guidelines for management of transmission of HIV and sexual transmitted infections in sexual assault, 2003. Website: www.doh.gov.za/aids/docs/ progress.html (Accessed 12.02.2010).

20. Campbell L, Keegan A, Cybulska B, Forster G. Prevalence of mental health problems and deliberate self-harm in complaints of sexual violence. J Forensic Leg Med., 2007; 12(2):75-8. 